\title{
ENTRE NINA RODRIGUES E ARTHUR RAMOS DIÁLOGOS POSSÍVEIS
}

\section{Wilton Alves Ferreira Junior. ${ }^{1}$; Rinaldo César Nascimento Leite ${ }^{2}$}

1. Bolsista PIBIC/CNPq, Graduando do curso de Licenciatura em história, Universidade Estadual de Feira de Santana, e-mail: wferreira.juniorestudante@gmail.com

2. Orientador, Departamento do Departamento de Ciências Humanas e Filosofia - DCHF, Universidade Estadual de Feira de Santana, e-mail: rinaldocesarleite@ hotmail.com

PALAVRAS-CHAVE: Eugenia; Racialismo; religiosidade.

\section{INTRODUÇÃO}

Entre as décadas de 1930 e 150 surge entre uma parte da elite intelectual a ideia de uma "Escola Nina Rodrigues", uma vertente de pensamento e atuação intelectual da qual fizeram parte o próprio Nina Rodrigues, Afrânio Peixoto, Oscar Freire, Diógenes Sampaio, e Arthur Ramos, entre outros. E que produziram diversos discursos sobre a questão do negro, raça e cultura no Brasil. Na pesquisa desenvolvemos um percurso historiográfico sobre a chamada "Escola Nina Rodrigues" onde observamos as pertinências do uso dessa ideia, e, em um segundo momento um estudo de caso onde observamos as abordagens de Nina Rodrigues e Arthur Ramos sobre a questão dos "Negros Maometanos na Bahia", e onde poderemos perceber como mais clareza as relações entre os dois autores.

Os nossos sujeitos são, o médico maranhense Raimundo Nina Rodrigues nascido em Vargem Grande, em 4 de dezembro de 1862, formado pela Faculdade de Medicina do Rio de Janeiro. Em 1889 se tornou professor da Faculdade de Medicina da Bahia, assumindo a cátedra de Medicina Legal em 1895, tornou-se amplamente conhecido por seu dialogo com as ideias racialistas de Cesare Lombrosoe Alexandre Lacassagne. Ao falecer em 1902, deixou cerca de 60 artigos. E, o médico alagoano Arthur Ramos nascido em Pilar, em 7 de julho de 1903, formado pela Faculdade de Medicina da Bahia. Em 1928, foi nomeado médico legista do serviço Médico do Estado da Bahia. Em 1935 Arthur Ramos assume a cadeira de Psicologia Social da recém-criada Universidade do Distrito Federal. Em 1946, de volta ao Brasil ocupa a cadeira de Antropologia da Faculdade Nacional de Filosofia da Universidade do Brasil, Ao falecer em 1949, deixou mais de 400 títulos publicados, entre livros e artigos.

\section{MATERIAIS E MÉTODOS}

Os materiais aqui utilizados são as obras "Os africanos no Brasil" de Nina Rodrigues, onde examinaremos o Capítulo intitulado "Os negros maometanos no Brasil" a fim de observar aspectos principais que dão sustentação ao discurso de Nina Rodrigues sobre a presença dos negros maometanos na Bahia do século XIX. E em " $O$ negro brasileiro" de Arthur Ramos aqui novamente centraremos no nosso olhar ao discurso de Arthur Ramos sobre a presença dos negros maometanos na Bahia do século XIX, em seu capítulo intitulado "O culto Malê". 
Trata-se essencialmente de uma pesquisa documental e bibliográfica, sob o campo da historiografia, trabalhando principalmente com a noção da análise do discurso de Eni Orlandi, na qual se estabelece um procedimento de questionamento, de decomposição e de reorganização dos discursos. Juntamente com a operação historiográfica de Michel de Certeau, que dá aporte para analisar os mecanismos da escrita da história, seguindo uma abordagem da história comparada.

\section{RESULTADOS E DISCUSSÃO}

Para Nina Rodrigues a "questão do o negro" estaria no cerne do debate para entender o passado o presente e o futuro do Brasil. A preocupação de Nina Rodrigues é conhecer ao máximo as influências históricas da "raça negra" no Brasil, para entender de que forma ela atua na constituição do povo brasileiro. Ao fazê-lo surge no discurso um olhar ao mesmo tempo darwinista social e evolucionista social: (RODRIGUES, 2010, p. 12). Já Arthur Ramos que se intitulava "o mais humildes dos discípulos [de Nina Rodrigues]" é um dos intelectuais dedicados à difusão do culturalismo no Brasil, a sua proposta é perceber como essas populações negras reagiram a um novo habitat, que influências sofreram a sua psiquê ao contato com as outras raças (RAMOS, 2001, p. 17), incorporando em seu discurso a Antropologia Cultural, ao mesmo tempo em que criava a Psicologia Social.

Durante o cotejo das obras podemos analisar a maneira como as obras se relacionam, em um ponto específico Rodrigues e Ramos vão tratar sobre as permanências fetichistas dos negros maometanos, Nina Rodrigues, enquanto evolucionista social, atesta que o monoteísmo Islâmico por suas abstrações complexas, seria uma religião superior, mais evoluída, exigiria uma capacidade intelectual maior de seus adeptos. Assim na lenta marcha do progresso civilizacional, os negros maometanos estariam um passo a frente dos praticantes de cultos politeístas ligados à fertilidade, principalmente dos grupos bantu-iorubano, mas que devido à sua capacidade religiosa primitiva ainda se utilizavam do amálgama de práticas fetichistas para poder assimilar uma religião mais complexa.

Tão fetichistas como os negros católicos ou do culto iorubano, os Males da Bahia acham meio de fazer dos versetos do Alcorão, das águas de lavagem, das tábuas de escrita, de palavras e rezas cabalísticas, etc., outras tantas mandingas, dotadas de notáveis virtudes miraculosas.(...) Possuo grande coleção de gris-gris, mandingas ou amuletos dos negros musulmis (RODRIGUES, 2010, p. 69 a 70$)$.

Os malês - chamaremos assim com o uso os negros muçulmis — são adeptos, no Brasil, de um islamismo sui-generis e mais se transformou aqui, ao contato com outras formas religiosas. (...) negros muçulmis, cônscios da sua superioridade e por isso mesmo calados e reservados nas suas crenças não só em relação aos seus irmãos fetichistas (...). Mas, embora com esse arremedo de monoteísmo, não se separaram de seus talismãs ou mandingas (...).(RAMOS, 2001, p. 72 a 73).

Para Nina Rodrigues o fetichismo e o sincretismo religioso dos negros maometanos, demonstravam uma dificuldade por parte dos negros em ascenderem na 
hierarquia social, embora, esta conversão ao monoteísmo já seja considerado para o autor como um avanço significativo. Para Arthur Ramos o monoteísmo também é entendido como uma evolução cultural embora preso a permanências da psicologia social, entendendo os "fetichismos" como manifestações culturais resistentes às religiosidades mais sofisticadas e lógicas.

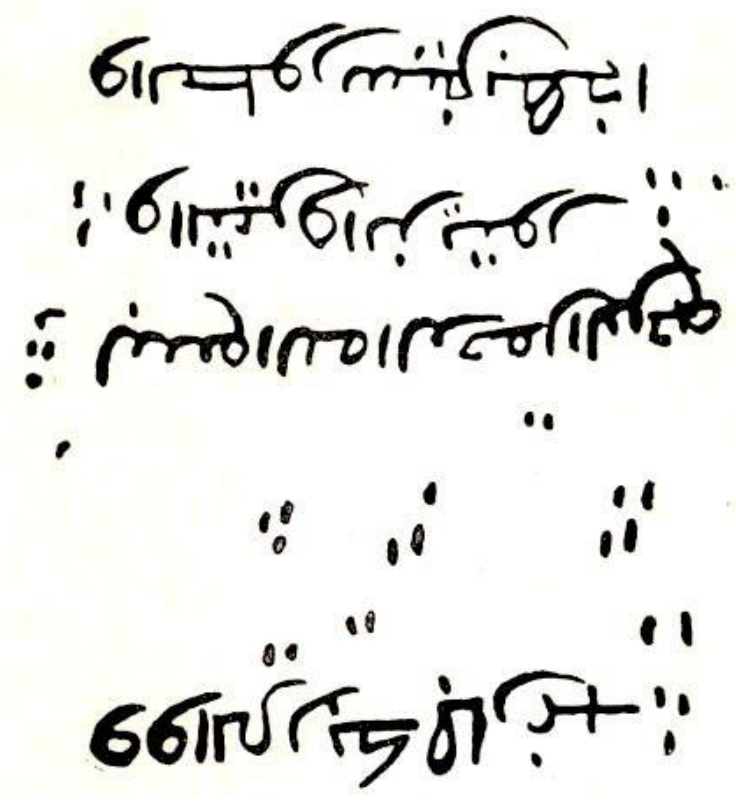

Figura 1: Mandinga ou amuleto dos negros mulsumis, retirado de "Os africanos no Brasil" (RODRIGUES, 2010, p. 182).

\section{CONSIDERAÇÕES FINAIS}

Durante a pesquisa percebemos que a "Escola Nina Rodrigues", se constituiu enquanto um grupo de intelectuais e eruditos das décadas de 1920 e 1930 principalmente médicos, dentre eles Arthur Ramos, que procuraram desenvolver pesquisas em áreas como a medicina-legal, a psicologia e a antropologia - o problema do Negro. Revindicando para si uma identidade de pertencimento a uma linha de pesquisa de Nina Rodrigues, como um dispositivo de oposição a uma um grupo hegemônico, o Freyreano, cuja perspectiva sobre as relações raciais, estava alicerçada na mestiçagem. Essa relação de ideias entre "mestre" e "discípulo" muitas vezes correspondeu a aproximações claras, mas em outros momentos, a grandes distanciamentos.

Ao se dedicaram a investigar sobre os negros maometanos na Bahia, estiveram muito próximos em estratégia discursivas, ainda que muitas vezes chegando a conclusões diferentes. Os grandes postulados do darwinismos social e do evolucionismo social presentes no texto de Nina Rodrigues são reelaborados por Arthur Ramos sob um viés culturalista. A pesquisa nos ajudou a perceber que nenhum dos autores, ao propor suas análises, limitaram-se ao viés exclusivo da medicina, embora ambos em momento 
algum deixem de lado os problemas e os olhares de suas profissões de formação. Esses autores vão buscar em outras áreas os subsídios para o entendimento de seus problemas.

\section{REFERÊNCIAS}

\section{Fontes documentais:}

RAMOS, Arthur. O negro brasileiro: etnografia religiosa. Rio de Janeiro, Graphia, 2001.

RODRIGUES, Nina. Os africanos no Brasil. Rio de Janeiro: Centro Edelstein de Pesquisas Sociais, 2010. 303 p. ISBN: 978-85-7982-010-6. Available from SciELO Books http://books.scielo.org

\section{Referências:}

BARROS, José D'Assunção. História Comparada - um novo modo de ver e fazer história. In: Revista de História Comparada. Junho 2007, v.1, n.1.

CERTEAU, Michel de. “A Operação Historiográfica”. In: A Escrita da História. Rio de Janeiro: Forense-Universitária, 1982, p.56-108.

CORREIA, Mariza. As ilusões da liberdade: a Escola Nina Rodrigues e a Antropologia no Brasil. Bragança Paulista, BP: EDUSF, 1998.

GUTMAN, Guilherme.. Raça e psicanálise no Brasil. O ponto de origem: Arthur Ramos. In: Revista Latinoamericana de Psicopatologia Fundamental, v. 10, p. 711-728, 2007.

ORLANDI, Eni. Análise de Discurso: princípios e procedimentos. São Paulo: Pontes, 2001.

RAFAEL, Ulisses N. . O não dito na obra de Arthur Ramos. In: Sociedade e Estado (UnB. Impresso), v. 24, p. 491-507, 2009.

REIS, João J. Os filhos de Alá na Bahia. In: Rebelião escrava no Brasil: A história do Levante dos Malês em 1835. São Paulo: Companhia das Letras, 2003.

SCHWARCZ, L. K. M.. O espetáculo das raças. Cientistas, instituições e pensamento racial no Brasil. São Paulo: Companhia das Letras, 1993.

SOUZA, Thyago R. G. A epopeia do negro brasileiro: a produção da república dos palmares na escrita de Arthur Ramos. 2014. 223f. Dissertação (Mestrado em História) - Centro de Ciências Humanas, Letras e Artes, Universidade Federal do Rio Grande do Norte, Natal, 2014.

SOUZA, Thyago R. G.. De Nina Rodrigues a Arthur Ramos: a reinvenção de Palmares nos “estudos do negro”. In: Temporalidades, v. 5, p. 161-180, 2013. 